\title{
CULTURAL IDEALS: \\ CHANGES IN PATTERNS OF KNOWLEDGE (FROM THE POINT OF VIEW OF READING HISTORY)
}

\author{
ISTVÁN MONOK \\ University of Szeged \\ monok@bibl.u-szeged.hu
}

\begin{abstract}
The present study started out by posing the question: what reasons might lead to the success of Hungarian intellectuals who were schooled in Hungary and who later emigrated to the West. From among the possible answers, we examined one: education and reading culture in Hungary was more complex in a given period than in Western Europe. We consider whether or not this answer is persuasive.

Based on the results provided by basic research in reading history in Hungary in the early modern period, one can safely say that the culture of experts in Hungary was more heterogeneous, and these experts constantly revisited traditional sources and kept them alive. On the other hand, in terms of the depth of professional knowledge and the level of concentration on a given field they were lagging behind their contemporary colleagues in Western Europe. This situation produced a dual effect: experts in Hungary had a stronger sense of tradition and they looked for transitional solutions due to the lack of the latest technical development and literature. Out of the Hungarian context, however, they produced outstanding achievements thanks to the more heterogeneous nature of their expertise.
\end{abstract}

Keywords: Central Europe, Hungary, Early Modern Period, Book History, Reading History, Memory History, History of Intellectual Movements

There are a number of permanent elements in general thinking and discourse which could historically be considered as topoi. These topoi were formed in different historical periods and were reinforced or weakened by the "gravitational force" of the institutional system of any given period, along the lines of material and political interests. One such topos is the one often cited and reinforced by folk wisdom and also by the Bible ("no man is a prophet in his own land") when referred to intellectuals who left Hungary and became exceptionally successful in their new environment. To prove this, Nobel Prize winners are cited who were schooled in Hungary but became world famous somewhere else. We also bring up examples where a Hungarian country doctor becomes outstanding in diagnostics in the international arena after moving abroad. We can carry on and bring up examples, the list is long.

What is the reason behind this success? Is leaving behind a poor professional background (poor because there is a lack of books, instruments and recognition) 
where one of the dominant national character traits is to pull each other back is, what provides the energy for emigrants or is it due to the need to prove themselves in a foreign environment and to provide for their families? Studying the readings of intellectuals and more broadly those of the general population of the Hungarian Kingdom and Transylvania in the early modern period one is tempted to say that reading history can also provide an answer to this question. Of course, it is not the only possible answer because there is no such thing as the exclusive answer. On the other hand, the key to this question offers food for thought for us living now, both choosing to leave or stay in our homeland.

Not counting the individual studies made by a few outstanding historians who pointed out the importance of the issue, institutionally organized research into the sources of the readings of intellectuals in the early modern period started almost four decades ago in 1979. ${ }^{1}$ Because of this, the books of more than two thousand private or public libraries have been documented from the two centuries after the Battle of Mohács (1526) and almost as many from the eighteenth century. These book lists from the sixteenth and seventeenth centuries have almost all been published, while only selected documents from the eighteenth century are available. ${ }^{2}$ These sources become even more interesting when compared to the ones representing the same documents of the Western European cultural communities. ${ }^{3}$

The first observation comes as a natural consequence of the state of the Hungarian and Transylvanian publishing, namely from the fact that very few books came out in the Carpathian basin in the above mentioned period $\left(16^{\text {th }}-18^{\text {th }}\right.$ centuries). Let me mention a few figures to illustrate the difference. In the sixteenth century, almost 150.000 titles were published in German speaking territories similarly to French and Italian regions. The same figure in Hungary and Transylvania together was not even one thousand. The number of all the European titles in the same century was around half a million while in the seventeenth century the entire European book titles went up to one and a half million while the corresponding number in Hungary and Transylvania together did not reach six thousand. This latter number radically rose in the eighteenth century and reached more than twenty thousand. One cannot help but draw sad conclusions from these comparisons but if we take the figures provided by the database produced during the abovementioned basic research, we can find some facts to console us. Contemporary booklists and library catalogues, in fact, show us that 7-8 \% of the European book production in the sixteenth century was present in the Carpathian Basin at the time. Unfortunately, this rate went considerably down by the end of the eighteenth century. Since then, the amount of books from European sources that has reached the Kingdom of Hungary or - since 1924 - Hungary has remained insignificant. ${ }^{4}$ One can also add to this relatively favourable rate in the sixteenth and seventeenth centuries that until the first third of the seventeenth century new European books arrived in Hungary just one or two years after their publications. 
Therefore, we can safely say that then intellectuals in our region were alert to what was going on in Europe even when they were in arms. (Let us not forget that the Kingdom of Hungary and Transylvania were at constant war in the sixteenth and the seventeenth centuries and several times during these centuries, the whole country suffered military campaigns.) In the history of reception, this up-to-datedness diminished in the seventeenth and especially in the eighteenth century when the products of the intellectual trends in Western Europe reached the Eastern countries of the Holy Roman Empire more and more belatedly. (It would be very interesting to study the reasons for this but that would divert us from our present topic.)

It follows from the statements above that the sources of reading history rendered unambiguous and full of meaning the conclusions drawn from the history of the system of educational and cultural institutions, namely that the culture of Hungary and Transylvania, or more broadly that of the peoples in Central Europe, was of a receptive nature. This phenomenon, which came about in the Middle Ages in a matter of fact way when Christianity was adopted belatedly, got reinforced in the early modern period. When, after King Mathias and the Jagiellonian dynasty, the Hungarian Kingdom lost its role as a power player in Europe all chances were lost for building an institutional system suitable for a country in power position within the history of European culture. This institutional system would have allowed intellectuals in this region to create an intellectual output that would have been more than a mere follower of West European trends. I mean intellectuals "from this region" and not "Hungarian" intellectuals since the scientific and cultural organizational output of the royal court in Buda during the reign of King Mathias and the kings of the Jagiellonian dynasty, which was measurable on a European scale, cannot be attributed exclusively to Hungarian Humanists or even Humanists living in Hungary. ${ }^{5}$

In Hungarian history and cultural history as well, it is a fact that the country has not been independent economically and politically until today. It all started in the sixteenth and seventeenth centuries when the Hungarian Kingdom was torn apart and had no king who would have lived in the country or a royal court within the country until the end of the political institution of kingdom in 1924. In the 21 st century, the independence of a small country is a relative phenomenon only.

At the same time the receptive nature of our culture provided a kind of openness for acquiring the output of other cultural and ethnic groups (not yet nations) and the knowledge of more than just someone's learned profession. Interdisciplinary was, therefore, a coded basic value that was adopted by the intellectuals in Hungary, in part out of necessity, due to the lack of books and the rarity of new books.

At the present stage of research, thorough and long studies and analyses of sources on reading history exist only for the sixteenth and seventeenth centuries, 
while basic research is sporadic for the period between the eighteenth and twentieth centuries, occasionally with penetrating case studies. Therefore, let me cite here the general conclusions one by one concerning the two centuries after the defeat at the Battle of Mohács in 1526. I will compare the validity of these conclusions based on sources with the knowledge we have from the periods afterwards.

I mentioned how small publishing industry was in this period. However, one can draw many conclusions from the changes that occurred linguistically and as far as the contents of these small numbers of newly published books are concerned. Studying the volumes of our retrospective national bibliography (Hervay Ferenc, ${ }^{6}$ Borsa Gedeon, ${ }^{7}$ Péter Katalin, ${ }^{8}$ Holl Béla, ${ }^{9}$ Tarnóc Márton, ${ }^{10}$ V. Ecsedy Judit, ${ }^{11}$ János Heltai, ${ }^{12}$ Csaba Csapodi ${ }^{13}$ ) one can notice a tendency towards secularization in the second half of the sixteenth century. The following fifteen years continued this tendency but after the destructions caused by the Fifteen Years War (Long Turkish War) and due to the fact that the Protestant churches became orthodox pushed into a defensive position by the organized re-catholization one can notice a re-theologizational process in the seventeenth century. The sources studied so far also pointed to this tendency. When one studies the reception of European intellectual trends, we can state that the nature of the reception changed from up-to-date in the first decade of the seventeenth century to 30 years lagging behind by the end of the century. Disregarding some outstanding intellectuals and aristocrats, this belatedness grew even more pronounced by the eighteenth century, not to mention the fact that mainly books in Latin were read right after they were published. These books in Latin were either theological tracts or translations (translations were by definition made after the book was written) since most of the ethnic groups by then used their own languages to write books.

A similar tendency can be seen when studying the contents of the books published in the Hungarian Kingdom and in Transylvania. ${ }^{14}$ It is true that in Transylvania the proportion of Latin books was smaller among the publications than in the Hungarian Kingdom (where the official language remained Latin until 1844). The proportion of Latin books imported to both countries grew from the second half of the seventeenth century, which means that, besides the fact that the new discoveries in science were generally written about in modern languages, more and more old books were bought since these were cheaper and written in Latin.

Readings became archaic from another point of view as well: the books published in Hungarian were in the eighteenth century also books by Antique authors or at times by writers of the sixteenth or seventeenth centuries or contemporary theological pieces for daily religious practice. Anyone reading in Hungarian therefore did not necessarily learn anything up-to-date. It is symbolic that Antonio Guevara's Mirror for Princes was translated at the end of the sixteenth century (it was considered contemporary then). This book was accompanied by translations of several contemporary pieces (Justus Lipsius, King James, Georg 
Ziegler etc.). The same books were translated again even at the beginning of the eighteenth century and were cited by our politicians of the Reform period at Parliamentary debates in the first half of the nineteen century. As late as the second half of the nineteenth century, in the twentieth century or even after 1989 , lectures on history were held in the Hungarian Parliament, when moralising Antique authors were cited not in a scholarly manner or precisely, disregarding the numerous MPs who had left their university chair or academia to be politicians. (Let us not think, however, that by now Parliamentary speeches were modernized in a way that intelligent politicians represent the interest of their clients from a pragmatic standpoint using the expertise of ars politicae. Archaism is gone by now, but modern political thinking has not appeared. The political arena is dominated by people who have never been forced to provide for themselves and their families using the profession they learned. After graduation, their careers began in high positions thanks to political connections.)

However, let us not rush forward in time and let us return to the changes of cultural ideals that occurred around turning points in different stages of reading history. By the beginning of the early modern period or the first decade of the sixteenth century an institutional system conform to that of Western Europe were formed in the Hungarian Kingdom. The density of this system, however, was not up to the level of the institutional system in Western Europe. The number of parochial schools radically grew and there are examples (e.g. in Székesfehérvár and Buda) where a university graduate was hired as a priest. "Humanist schools" were formed in towns. A good example of this is the Szalkai Codex (The School of Sárospatak). More and more members of middle clergy were university graduates, ${ }^{15}$ certain prebendaries had staff members who had been to Italy (e.g: the Prebend of Gyulafehérvár). Libraries were founded to store the written part of European heritage some of which were considered very modern at the time. Let me refer here to the 24 Parochial Brotherhood of County Szepes (Fraternitas XXIV plebanorum civitatum regalium), established at the end of the fourteenth century, ${ }^{16}$ which founded a library that became the public library of Lócse at the beginning of the sixteenth century. Another example for this in the kingdom of Hungary is the public library of the town Pécs, which was established in 1477 from the generous donation of György Handó. ${ }^{17}$ Andreas Hess installed his press in Buda in 1473. The next officina was established in Brassó only in 1525 but in between these two dates Hungarian patron church officials and aristocrats ordered many books from Venice, Augsburg, Basel or Hagenau but also elsewhere. ${ }^{18}$ Transitional forms of biliophilia were also known as incunabula and early publications were highly valued but hand copied and illustrated codices were held in the highest esteem. The ideal for learning at the turn of the fifteenth and sixteenth centuries was deeply personally religious. To put it in a different way, the tradition of Saint Augustine's Confessions or Saints Bernard, Francis or 
Claire or the tradition of the Fraternity movement in the fourteenth and fifteenth centuries, the tradition of Imitatio Christi, the tradition of confraternitas, were all alive in the Hungarian Kingdom even more so with the spread of Protestant ideas $^{19}$ as well as Humanism with its linguistic and philological message and Christian philosophy (Erasmus). Hungarian language profited from this dual tradition (not independently from the influence of Jan Hus although Husitism played no part here). The Protestant turn in the sixteenth century happened very fast because the school and educational ideals outlined in the Protestant Principles, in Martin Luther's Sendbriefs or in Philipp Melanchthon's university lecture were based on this dual tradition. In the fast spread of Protestantism, the breakdown of the hierarchy of the Catholic Church was also instrumental which was partly due to the fact that a great number of the high clergy found their death at the battle of Mohacs. The intellectual trend that helped the peaceful co-habitation of different denominations and aimed at unification against the Turks (Turkish Empire, not Islam) was always popular in Hungary or Transylvania. It is conspicuous how up-to-date the presence of European intellectual trends was: Irenic thoughts in theology, Christian Neo-Stoicism in Philosophy, the thought of Unio Christiana in Political Theory and plans to expel the Osman Turks in political practice were all thoughts acceptable or desirable for aristocrats or gentry pursuing intellectual professions or for townsfolks. The scientific crisis of Western Europe ${ }^{20}$, the appearance of Sceptic thoughts due to the fact that the phenomena of the discovered New World could not be grasped in the traditional Antique or medieval terms, which made it necessary that a new scientific model, a New Organon must be devised, all this scientific discourse only sporadically appeared in the Carpathian Basin. However, the change in the logic system, the new applied logic of Petrus Ramus or Bartholomäus Keckermann can mostly be detected in education, in the change how the knowledge transmitted at school was arranged. All this was topped by Jan Amos Komenský with his personal presence and educational and school programme (Orbis pictus).

From the middle of the seventeenth century the turning points of the major European thoughts and history of mentality were transmitted in the Hungarian Kingdom or Transylvania as the teachings of a "spiritual father" (such as Erasmus, Melanchthon, Justus Lipsius, or David Pareus) but through the influence of authors of the second rank, the direct disciples or university professors. Let me bring here one example: Horst Dreizel created a typology based on the teachings of the key thinkers in Protestant ethics from Melanchthon to Pufendorf ${ }^{21}$, from the Protestant Ethics of late Humanism to the deep religiousness of the early enlightenment through the Aristotelian and Platonist tradition. When checking the names of the abovementioned authors in the database of the readings available in the Hungarian Kingdom and in Transylvania we have very few matches while we can find the names of the followers and disciples or opponents of these philosophers in the database. 
The turning point around 1670 in the European history of science 22 had its impact in Hungary already half a century late and appeared at the same time as the ideas of early enlightenment transmitted by the Germans. In history, this is the period between the two great power pacts, the Peace of Westphalia and the end of the War of the Spanish Succession. In Hungarian history, this is the period of the Tartar invasions (1658-1717), which changed the ethnic composition of the country, the military campaigns that resulted in the expulsion of Ottoman Turks from Hungary (1664-1699), the Imre Thököly Uprising as well as Ferenc II Rákóczi's War of Independence (1703-11). A page in history was, once and for all, turned here. This also brought along the destruction of a significant number of educational and cultural institutions.

An important element of the change in educational ideals is the successful reform the Catholic Church carried out after the Council of Trent and the implementation of a Catholic school system (by Jesuits and Piarists). This latter was so successful that, for the first time in history, they managed to found a university in 1635, which has been active ever since. With the Piarists, a modern change occurred at schools similarly to the one that took place in Western Europe in academia. With the birth of new science models the importance of certain disciplines increased. Philosophy, history, geography and modern languages replaced theology in the forefront of academia. Rational scientific thinking was in the focus, which made the supporters of traditional educational ideals focused on faith; religion and theology choose different types of orthodoxy along the dual lines of personal devotion and humanism, which resulted in the reinforcement of intellectual trends such as pietism and Jansenism. On the other hand, on the side of ratio, scientific thinking became dominant. (Lutherans schools followed this trend fast especially thanks to Mátyás Bél's activity at the Lutheran Lyceum in Pozsony and later on at the College of Reformed Church in Debrecen in the 1740s.)

On the side of ratio the secularisation of science also moved forward ${ }^{23}$ but this secularisation could not take place in the Hungarian Kingdom or in Transylvania. Here the population was poor and there were very few books available. There was no active book trade, therefore people were more dependent on the institutional collections (of schools or of the church or of other public institutions) and in Transylvania on the private libraries of the land-owning aristocrats of the area until as late as the beginning of the nineteenth century ${ }^{24}$.

Another factor which one has to bear in mind when studying educational ideals is language, the lingva franca of Western Europe on one side and the vernacular languages of the cultural communities of the Hungarian Kingdom and Transylvania on the other side. Latin language as well as Christianity provided the basis for European culture from the collapse of the Roman Empire in 800 A.D. and the compromise made between church and secular powers. The school system was built on this basis within which the institution of universitas 
emerged in the eleventh century, and the network of book culture (copying workshops, libraries, then publishing houses and later the book trade were established. The key conflict in the deepening of Christianity was that devoted believers needed their mother tongue for their prayers and for learning about their faith as opposed to the church as an institution where Latin was the language used. Townsfolks and later on rulers also realized that vernacular culture is also a cohesive force just like belonging to a commonly shared religious community. Some kings initiated a program to develop vernacular culture to counter the Catholic Church (as did Henry VIII in England). The process ended in the French Revolution but it took place differently in different regions.

In the Hungarian Kingdom and Transylvania but also in the entire Central European Region (Europe Between/Zwischeneuropa) the church played a completely different role in the early modern period than in the West. The church, therefore, could not be excluded by the news of the French Revolution from shaping educational and cultural ideals. It was the churches, often seriously understaffed (see the institution of licenciation or appointing laic priests as well as György István Tóth's image about the illiteracy of priests ${ }^{25}$ ), who held the communities together.

The Lutheran Church kept the Lutheran Hungarians and Slovaks together ${ }^{26}$ and there were Slovaks who joined the Reformed Church, although not in great numbers. ${ }^{27}$ In Transylvania, language differences reflected the ethnic divide. Until the nineteenth century, there were very few Hungarian Lutherans, the same way, as there were very few Saxons or Romanians among the Calvinists. ${ }^{28}$ The high clergy of the Hungarian Catholic Church in the eighteenth century had to meet the requirements of universal Christian principles, their family traditions (mainly aristocratic ones), they had to meet the expectations of the country and they were supposed to be loyal to the king. Their role was manifold as was their church. Therefore, the society's judgement about what the churches stood for was also complex. One can talk about the secularisation of science and educational ideals with great caution up until the middle of the nineteenth century.

In the changes of Western European cultural trends one could always detect a return to the Antique or the early Christian roots. Including Jewish culture into the Western tradition took place late in the second half of the eighteenth century (Gotthold Ephraim Lessing, Moses Mendelssohn) in spite of the oeuvre created by Johann Reuchlin and his associates as well as the collegium trilingve. This reinterpretation always took the form of a new critical publication of the pieces written by Antique authors or the Church Fathers. These newer and newer editions were available in the libraries of the Hungarian Kingdom and Transylvania and the newer editions were in deed read as is shown in the philological study of the not so numerous Hungarian translations.

Following Western examples, a little belatedly, Hungarian language started to be valued as a part of the educational ideals. Besides using Hungarian in monas- 
teries as well as for translations, Humanist scholars set out to study Hungarian influenced by Erasmus. At the turn of the sixteenth and seventeenth centuries protestants were, in fact, oriented towards the vernacular and set out a programme to translate the books of the classical authors into Hungarian, with no delay after these were published abroad, as a way of receiving Western intellectual trends and catching up with Western nations. The seventeenth century brought a turning back with regard to this as well. A vernacular programme would not be planned again until the last third of the eighteenth century when it did yield some results. In Transylvania, however, this process took place in a different way since here the language of administration was Hungarian and not Latin. Unfortunately, financial support was little, therefore, the efficiency was not great. The libraries in Transylvania, however, had more books in Hungarian than the ones in the Hungarian Kingdom.

The eighteenth and nineteenth centuries brought a new turn with a new period of reinterpretation. Not because many text variants were unearthed, like in the first half of the sixteenth century. Not because the new discoveries broke down the models we had had from Antiquity as it happened at the turn of the sixteenth and seventeenth centuries. Revisiting our Antique heritage was aimed at resolving the contradiction between culture and civilisation, or human and scientific. This process was long starting with Bartolomé Las Casas through Voltaire to the aesthetics of Schelling and the "distant lands" of the Romantics. This reinterpretation defined the cultural tastes of several generations from Lessing through Schiller and Novalis to the Schlegel brothers and contributed to the Greek influence to be included into our "Kulturheimat" with the discoveries of the Byzantine relics from the period of the Ottonian Dynasty at the end of the eighteenth century.

I find it very important to stress that each new reinterpretation had a deep impact on its period. Authors did not just reinterpret the past but past were integrated into the educational and cultural ideals of the present. ${ }^{29}$

In his ground-breaking book on the ideals of Hungarian education and culture ${ }^{30}$ Gyula Kornis provided a typology. He also described the conflicts in taste and in politics along the lines of economic interests. Those who wanted to modernize the society by loosening feudalistic obligations, by extending the use of literacy and by implementing reforms in state administration were of the Habsburg royal court. By doing this, they forced in the background the values and the interests of the champions of vernacular education in culture. These latter ones included aristocratic families, high clergy, town bourgeoisie or educated gentry. Those who stressed the importance of the values provided by classical education in Latin criticised the import of Western intellectual trends translated into modern vernacular languages when the ones carrying classical values could not yet be read in vernacular. It is important, however, to note that beside classical ideals 
the new technical development and science also gained ground. Kornis calls this new Humanism because in it, German and Hungarian Neo-Humanism met science. This period reinforced the belief that scientific, technical and technological thinking could replace the other, non-rational humane side. (The same thought in an extreme form appeared many times at the end of the twentieth century and at the beginning of the twenty first century. It even became dangerous since rising politicians who replaced the old political elite used it for their fake pragmatic and fake modernist rhetoric to cover up their own lack of learnedness.)

As far as the number of published books is considered, there was a relatively fast growth from the second half of the eighteenth century with more and more books being written in vernacular, especially in Hungarian. When the books read are considered, one notices that the strata of society who were readers were growing farther and farther away from each other. Aristocratic libraries in the period between 1750 and 1830 can be considered modern from a linguistic and thematic point of view if the Western European model was what you call modern. On the other hand, if the readings of schoolteachers in villages both in Catholic counties such as Vas, ${ }^{31}$ Veszprém-Zala, ${ }^{32}$ and Bihar ${ }^{33}$ or in a Calvinist one such as Bereg ${ }^{34}$ are considered, they are far from being up-to-date. The libraries of smaller educational institutions are poor and out-of-date. The collections bequeathed to these libraries did increase the holding and improved the level as far as contents went but could never make the library modern or up-to-date. (This is the case with libraries now in Hungary.)

More books, more books in Hungarian and the very slowly widening circle of readers posed a problem for the champions of traditional values in the Hungarian Kingdom. It was not simply due to the fear the church had that they would lose their capacity to control educational ideals. It depended on the authors but the fact that already in 1792 Vazul Alexovics, Pauline father, university lecturer and a little later in 1832 Antal Laszkalner, Prebend of Veszprém wrote about this ${ }^{35}$ indicates this process. The enlarged edition of the latter tract $(1848)^{36}$ is a piece in the history of Philosophy in Hungary, which has not been fully recognized for its merits since apparently the author knew the contemporary, or near contemporary trends in German ontology and epistemology. Therefore, his critique on not choosing readings well and his guidelines to reading was not motivated by the church's point of view. Menyhért Palágyi ${ }^{37}$ at the beginning of the twentieth century continued this tradition even if he did not refer to Laszkalner when he emphasized how important it was to use methods in teaching reading, which was not experimental but based on tradition (this has mainly been disregarded by methodologists these days). The emergence of functionally illiterate masses now in Hungary and in the world in general is the direct result of the unfounded experiments in teaching reading and writing in the 1980s. Palágyi put it in the following way in 1904: "To be skilled in silent reading first you have to learn 
reading out aloud. The same way to master the skill of thinking to yourself first you have to learn how to think aloud and to attribute meaning to audible or visible signs. Therefore, if someone has not learnt in their childhood how to read meaning into audible signs then they cannot reach phases of their life when they manage to think while immersed in themselves without any creation of signs." ${ }^{38}$ In nature there are no leaps, there will not be any in the age of robots. It is not by chance that audio books are so popular with not necessarily only people with weak eyesight. However, let us return to the turn of the eighteenth and nineteenth centuries.

With the Napoleonic era, traditional European culture, based on the compromise of power between the pope and the emperor, ended. The church slowly lost control of educational and cultural ideals by the middle of the twentieth century, even in the Central European region. The carrier of Hungarian educational and cultural ideals became the Hungarian language, but the orientation towards classical Antique values remained until Communist times even among those who did not follow the traditional Humanities type schooling. French being lingva franca for a short time did not get socially accepted on all levels and stayed within the sphere of the aristocrats and elite intellectuals. German, however kept and even reinforced its role in the nineteenth and twentieth centuries as the channel through which our region received the latest results in technical civilisation or trends in major European intellectual ideas. More and more people in Hungary paid attention to the products of English civilisation, following in Sándor Bölöni Farkas’ or István Széchenyi’s footsteps. Some of our national classical authors, such as Mihály Vörösmarty, or János Arany, ${ }^{39}$ built up quite a Shakespeare cult. Despite all this, until now there has not been direct English influence in the Hungarian Kingdom or Hungary (due partly to the indifference on the English side.)

The industrialisation of publishing made open access to culture for the bourgeoisie. Books were published in great number and became cheaper. This change was Janus faced and has remained ever since. One can make use of technological development and one can abuse of it. The feudal right of jus usi et abusi has still persisted even if we label them with adjectives such as "democratic" or "open society". From the middle of the nineteenth century in the Hungarian Kingdom, as well as in Transylvania, and especially from the Austro-Hungarian Compromise of 1867 the press had a more and more important role in changing educational and cultural ideas. If a circle of intellectuals wanted to spread its own ideas of quality, they could. An example for this was the series entitled "Good books" with which first rate novelists such as Mór Jókai, Kálmán Mikszáth, and others wanted to counteract the impact of popular fiction (besides seizing a good business opportunity for themselves and for the publishers.)

Unfortunately, media (journalism reinforced with the radio, television and in part with the options provided by the internet) became an ally to power and 
replaced church entirely. Media gave up its freedom if ever there has been free press independent from its owner. Publishers in Hungary today all say that preference in reading is shaped by the press. It requires a great deal of investment to counteract its impact, which is rarely a profitable enterprise. Publishing is an enterprise to produce profit. If European intellectuals would like to protect Europe from phenomena such as les mémoires brulées then they should make sure that media is free and independent from its owners and it does not serve their purposes.

The Information Age with economic globalisation in the background offers many opportunities for creating new ideals for culture and education. At the same time, it also carries many dangers and traps. A lot of us know the book by Archibald MacLeish "America Was Promises" (1939) which was translated into Hungarian and published in 1972 in a different context than the one it was written in and we Hungarians must have read it in a different light at the time ("De captu lectoris habent sua fata libelli"). I believe a lot of us in the world share the same worries and concerns as everyday people in America who believed in a dream and then were let down in great numbers. The internet is also a "promise", a tool of power. It is rather risky to base cultural ideals on it. Maybe if we had the time for "re-readings or re-evaluations": all texts from Antiquity onwards digitalised and posted on the internet in new critical editions - a nice vision few of us nurture. In the meantime, we are faced with the fact that the World Wide Web is definitely a business, its developers shape it according to their professional and information technology purposes. On the other hand, it is becoming a more and more important tool for the exercise of power. The idea or "the promise" the internet set out with that it is democratic and helps democratisation has proved wrong during its short, twenty-five-year-long existence.

Let me return to the aspects of reading history in the changes of cultural ideals. If one studies the book collection of an intellectual in Hungary in the second part of the nineteenth century or between the two World Wars, then one can say that these were more complex thematically than the library of a lawyer in Paris in the sixteenth century. A French lawyer then could find for himself a bookshop on rue Saint Jacques that specialized in legal books. He could therefore build for himself a specialised library. He became a true expert but in the meantime, his cultural horizon became rather narrow. If we consider Hungary today one can hardly find such specialised bookshops. A Hungarian lawyer of not only the sixteenth century but also from the 1930s could hardly realize such a goal so easily. On the other hand, because we have been lacking specialised books, we have read a large range of books. From the second half of the seventeenth century we can present examples for this, doctors, physicists or astronomers.

I find the results of surveys concerning reading habits noteworthy for Hungarian society. Unfortunately, we have not had such a survey in recent years. These 
surveys should be reinstated like the PISA survey, which measures the efficiency of education. There was such a study in Hungary in 1976 that was followed by surveys once a decade until the Big Read project in 2005. These surveys show that Hungarian society is not ready for a new cultural ideal. Changes like this require centuries. We do experience fast, even too fast technological development and the interests behind it will drive humanity into war. Humans do not evolve, neither do societies. Or if they do they do it at a much slower rate than technology. The result of the Big read project in 2005 in Hungary was that the most popular novel was "Egri csillagok" (Stars of Eger). Many intellectuals were rather unhappy about this result at their media events and would have preferred a more modern book. On my part, I find it rather reassuring since it shows we have something to build on. Among the 100 most popular Hungarian authors there were very few contemporary writers in 2005 . If we study the novels on the popularity list, the message is clear: intellectuals should not cut themselves off from the society they live in for nice ideals. The theory of literature (as well as contemporary critique) is more the theory of theory and not the theory of literature. Therefore, writers write for theoreticians (and maybe for themselves). History is more based on opinions than sources (I know that a source is what used to be an opinion as well) and now we have the theory of justification: memory history. ${ }^{40}$ Economic theories are slowly becoming the theory of theories and as economists say do not refer to "real economy". The "science of pedagogy" is bent more on self-reflection than finding solutions for everyday educational concerns although it could really help if it would not disregard it (and would pay more attention to and rely more on the history of ideas). Media referring to "media sources" organize and hold autodafes, and drag people through the mire more cruelly than inquisition has ever done instead of looking for sources and teaching young journalists how to read sources. In a world where everything has been lowered to and controlled by information, administration and power technique, intellectuals should re-read all cues, which have led us to the twenty-first century. Communities which have been abandoned by their intellectuals (priests and teachers) disappear and the peoples of Europe have been abandoned by them. In 2005 Hungarian society gave us a sign that they prefer the novelist Géza Gárdonyi (1863-1922) who worried about the lives of his protagonists Vicuska and Gergö or the Humanist Magda Szabó (1917-20007) who conversed with his father in Latin or the novelist Áron Tamási (1897-1966) who was mourning the emigration of Ábel, his protagonist. It would be high time we understood this message.

The present study started out by stating the question: what reasons might explain the success of Hungarian intellectuals who were schooled in Hungary and who later emigrated to the West. From among the possible answers, we examined one: education and reading culture in Hungary has been more complex in a given period than in Western Europe. 
Based on the results provided by basic research in reading history in Hungary in the early modern period one can safely say that the culture of experts in Hungary was more heterogeneous, they constantly revisited traditional sources and kept these alive. On the other hand, in terms of the depth of professional knowledge and the level of concentration on a given field they were lagging behind their contemporary colleagues in Western Europe. This situation produced a dual effect: experts in Hungary had a stronger sense of tradition and they looked for transitional solutions due to the lack of the latest technical development and literature. Out of the Hungarian context, however, they can produce outstanding achievements thanks to the more heterogeneous nature of their expertise.

To sum up the conclusion of the present study in one sentence let me state here that there is no creative knowledge without having some general non-professional knowledge as well. Alternatively, if there is, then that kind of knowledge is sufficient for one or two flares, but not for continuous renewal. There are no leaps in human nature (as we saw there is a reason behind learning to read by syllables), which is to say that without a sufficient amount of facts known actively, one's thinking will narrow down and one will have little innovative thinking even if one knows where to find these facts. The counterpoint of the "orthodoxy" of humanities and the "modernity" of science, re-visited in each period, has by now become an artificially maintained enmity as viewed by intellectuals today and dictated by power circles. As for its educational and cultural ideal, the latter one has embraced the slogan of global culture at a point in time when a small peninsula-continent (Europe) is incapable of establishing its consensus europaeus or citing an example from another culture, the peoples of Islam and their social strata are unable to create a commonly shared thought form or cultural ideal. Merging masses of people of differing cultural background has about the same potential: none at all. However, let us be optimistic, humans will solve this problem too.

\section{Notes}

1 Katalin Keveházi: "Aufarbeitung und Publikation von ungarischen Bücherverzeichnissen aus der Zeit vom XVI. bis XVIII. Jahrhundert.” Wolfenbütteler Notizen zur Buchgeschichte, 10(1985) 68-77.; István Monok: "Die buchgeschichtlichen Forschungen in Szeged, 19801995." Frühneuzeit-Info, 7(1996) Nr. 2. 253-258.

2 http://koraujkor.ek.szte.hu/lectio/koraujkor?p=0

3 István Monok: "Deux siècles de culture de la lecture dans le Bassin des Carpathes (15261730)." In: Le berceau du livre: autour des incunables. Études et essais offerts au Professeur Pierre Aquilon par ses elèves, ses collègues et ses amis. Sous la dir. de Frédéric Barbier. Numéro spéciale de la Revue française d'histoire du livre. Genève, Droz, 2003. 297-306.; István Monok: "Lecteurs et lectures en Hongrie: quelques aspects d'une histoire originale." Histoire et civilisation du livre. Revue internationale, 1(2005) 267-276.; István Monok: "Die Buch- und Lesekultur in Ungarn der frühen Neuzeit. Teilbilanz der Ergebnisse einer langen 
Grundlagenforschung (1980-2007)." Mitteilungen der Gesellschaft für Buchforschung in Österreich. 2008/1. 7-31.

4 In certain periods there were rising phases, e.g. the decades after The Austro-Hungarian Compromise of 1867 or during the period of the cultural policy initiated by Minister Klebelsberg and also perhaps surprisingly in the 1950s. Let me add here that many books were imported from the West then but only very few selected people were allowed to read them.

5 See: László Veszprémy: "The first centuries." - Géza Pálffy: "The bulwark and larder of Central Europe." In: Ont he stage of Europe: the millenial contribution Hungary to the idea of European community. Ed. by Ernő Marosi. Budapest, Balassi Kiadó, 2009. 67-99., 100-129.

6 Ferenc Hervay: “A XV-XVI. századi magyarországi könyvnyomtatás számokban.” (Printing in Figures in Hungary in the $15^{\text {th }}$ and $16^{\text {th }}$ Centuries.) Magyar Könyvszemle, 82(1966) 63-66.

7 Gedeon Borsa: “A 16. századi magyarországi könyvnyomtatás részmérlege.” (A Partial Assessment of Printing in Hungary in the $16^{\text {th }}$ Century) Magyar Könyvszemle, 80(1973) 249 269. (With Remarks by Ferenc Hervay and Csaba Csapodi.) Special Print: Reneszánsz Füzetek (Renaissance Booklets) 22. Budapest, 1973.; Same in: Gedeon Borsa: Könyvtörténeti irások. I. A hazai nyomdászat 15-17. század. (Writings in Printing History. Printing in Hungary in the $15^{\text {th }}$ to $17^{\text {th }}$ Centuries) Budapest, 1996 (Az Országos Széchényi Könyvtár Kiadványai. Új sorozat 6., Publications of the Hungarian National Széchényi Library. New Series 6.) 350-363.

8 Katalin Péter: "Aranykor és romlás a szellemi műveltség állapotaiban." (Golden Age and Decline in Erudition) Történelmi Szemle, 7(1964) 80-102.; Same, In: Papok és nemesek. Magyar müvelödéstörténeti tanulmányok a reformációval kezdödő másfél évszázadból. (Priests and Nobles. Studies in Hungarian Cultural History during 150 Years from the beginning of Reformation) Budapest, 1995 (A Ráday Gyüjtemény tanulmányai 8., Studies of the Ráday Collection) 77-97., 238-243.; Péter Katalin: "Ein Program für jedermann im Ungarn des 16. Jahrhunderts." In: Iter Germanicum. Deutschland und die Reformierte Kirche in Ungarn im 16-17. Jahrhundert. Hrsg. von András Szabó. Budapest, Kálvin Kiadó, 1999. 7-38.

9 Béla Holl: "Szerző, nyomdász, olvasó a 17. század első felében." (Authors, Printers, and Readers in the First half of the $17^{\text {th }}$ Century) Irodalomtörténeti Közlemények, 84(1980) 639-649.

10 Márton Tarnóc: “A magyar könyv a 17. század első felében." (Hungarian Books in the First Half of the $17^{\text {th }}$ Century) Magyar Könyvszemle, 89(1973) 315-331.

11 Judit V. Ecsedy: “A 17. század első felének nyomdai körképe és részmérlege - Druckwesen in der ersten Hälfte des 17. Jahrhunderts - Überblick und Bilanz." In : $\mathrm{Fe}$ jezetek 17. századi nyomdászatunkól - Studien über die ungarländische Typographie des 17. Jahrhunderts. Szerk./Hrsg. von P. Vásárhelyi Judit. Budapest, OSZK, Osiris Kiadó, 2001 (Libri de libris) 37-55.; V. Ecsedy Judit: "Hetven év nyomdai körképe és mérlege (1601-1670).” In: Sylvae typographicae. Tanulmányok a Régi Magyarországi Nyomtatványok 4. kötetének (1656-1670) megjelenése alkalmából. Szerk.: P. Vásárhelyi Judit. Budapest, Argumentum Kiadó, 2012 (A Magyar Könyvszemle és a MOKKA-R Egyesület füzetei, 5.) 11-33.

12 János Heltai: Müfajok és müvek a XVII. század magyarországi könyvkiadásában (1601-1655). (Genres and Books in Printing in Hungary in the $17^{\text {th }}$ Century), Budapest, Universitas Kiadó, OSZK, 2008 (Res libraria II.)

13 Csaba Csapodi: "Könyvtermelésünk a 18. században." (Book Output in Hungary in the $18^{\text {th }}$ Century), Magyar Könyvszemle, 60(1942) 393-398.; cf.: Judit V. Ecsedy: "Pillanatkép a retrospektív nemzeti bibliográfia 18. századi szakaszáról." (An Assessment of the $18^{\text {th }}$ Century Part of the Retrospective National Bibliography), In: Summa. Tanulmányok Szelestei Nagy László tiszteletére. (Studies in Honor of Szelestei Nagy László), Edited by.: Ibolya Maczák. Piliscsaba, PPKE, 2007. 64-68.

14 István Monok: "Nationalsprachige Lesestoffe in Ungarn im 16. und 17. Jahrhundert." In: Latein und Nationalsprachen in der Renaissance. Hrsg. von Bodo Guthmüller. Wiesbaden, 1998, 
Harrassowitz. (Wolfenbütteler Abhandlungen zur Renaissanceforschung. Bd. 17.) 137-150.; István Monok: "Les langues de la lecture dans la Hongrie moderne (1526-milieu XVIII siècle." Histoire et civilisation du livre. Revue internationale, 4(2008) 137-148.

15 József Köblös: Az egyházi középréteg Mátyás és a Jagellók korában. (The Middle Stratum in the Chruch Hierarchy during the King Matthias and the Jageollian period), Budapest, MTA TTI, 1994 (Társadalom- és mủvelődéstörténeti tanulmányok, 12. Studies in Social and cultural history 12.)

16 András Vizkelety: "Die Fraternitas XXIV plebanorum civitatum regalium in Oberungarn und der Handschriftenbestand Zipser Pfarreibibliotheken." In: Pfarreien im Mittelalter. Deutschland, Polen, Tschechien und Ungarn im Vergleich. Vom 30. November bis 2. Dezember 2006 am Max-Planck-Institut für Geschichte eine Tagung zum Thema Pfarreien in Mitteleuropa im Mittelalter. Hrsg. von Nathalie Kruppa. Göttingen, Vandenhoeck und Ruprecht, 2008. 327-338.

17 See: Csaba Csapodi: "Ungarische Bibliotheksgeschichte. Vom Mittelalter bis zum Frieden von Szatmár (1711)." Gutenberg Jahrbuch, 1984. 332-357.; About Georg Handó, see: Boda Miklós: "Handó György könyvtáráról egy pécsi emléktábla ürügyén." (The Histor og the Library of Georg Handó) In: Convivium Pajorin Klára 70. születésnapjára. Szerk.: Békés Enikö, Tegyey Imre. Debrecen-Budapest, 2012. 25-34.; Pócs Dániel: "Handó György könyvtára." (The Library of Georg Handó) Ars Hungarica, 42(2016) 309-338.

18 A budai könyvárusok kiadványai 1480-1525, (The Publications of the Book Sellers in Buda between 1480 and 1525) Data collected by Gedeon Borsa, edited by Sándor Dörnyei, is an excellent overview. In: Régi Magyar Könyvtár. III-dik kötet. (Old Hungarian Library, volume III, Hungarian Authors, A Handbook of non-Hungarian language publications which came out abroad from 1480 until 1711, Additions, supplements and corrections) volume 5. Budapest, OSZK, 1996. 249-282.; See: Gedeon Borsa: "L'Activité et les marques des imprimeurs de Buda avant 1526", in: Le livre dans l'Europe de la renaissance. Actes du XXVIII Colloque internationale d'études humanistes de Tours, sous la direction de Pierre Aquilon, Henri-Jean Martin. Paris, Promodis, 1988. 170-181.

19 See.: András Kubinyi: "Vallásos társulatok a késő középkori Magyarországon." (Confraternities in Medieval Hungary) Magyar Egyháztörténeti Vázlatok, 10(1998), 1-2. sz. 123-134.; Same In: András Kubinyi: Föpapok, egyházi intézmények és vallásosság a középkori Magyarországon (High Clergy, Church Institutions and Religious Faith in Medieval Hungary). Budapest, 1999 (METEM könyvek, 22.) 341-352.; Pál Ács: "The Theory of Soul-sleeping at the Beginning of the Hungarian Reformation Mouvement." In: Centers and Peripheries in European Renaissance Culture. Essays by Eat-Central European Mellon Fellows. Ed. by györgy Endre Szőnyi, Csaba Maczelka. Szeged, JATEPress, 2012. 95-104.; Zoltán Csepregi: "Bund, Bundschuh, Verbundenheit. Radikales Gemeinschaftsprinzip in der frühen Reformation Ungarns." In: Armed Memory: Agency and Peasant Revolts in Central and Southern Europe (1450-1700). Ed by Gabriella Erdélyi. Göttingen, Vandenhoeck und Ruprecht, 2016 (Refo500 Academic Studies (R5AS); 27.) 147-168.

20 See: Wissenschaftsgeschichte um Wilhelm Schickard. Hrsg. von Friedrich Seck. Tübingen, Mohr, 1981 (Contubernium, Bd. 26.) - hier especially (pp. 153-240.) Berthold Sutter: "Wissenschaft und geistige Strömungen zwischen dem Augsburger Reigionsfrieden und dem Dreissigjährigen Krieg."

21 Horst Dreitzel: "Von Melanchthon zu Pufendorf. Versuch über Typen und Entwicklung der philosophischen Ethik im protestantischen Deutschland zwischen Reformation und Aufklärung." In: Spätrenaissance-Philosophie in Deutschland 1570-1650. Entwürfe zwischen Humanismus und Konfessionalisierung, okkulten Traditionen und Schulmetapysik. Hrsg. von Martin Mulsow. Tübingen, Max Niemeyer, 2009 (Frühe Neuzeit, Bd. 124.) 321-398. 
22 Cf.: Die Zeit um 1670. Eine Wende in der europäischen Geschichte und Kultur? Hrsg. von Joseph S. Freedman. Wiesbaden, Harrassowitz, 2016 (Wolfenbütteler Forschungen, Bd. 142.) - hier: Joseph S. Freedman: "Introduction. The Period Around 1670 - Some Question to Consider" (pp. 7-74.), Jan Schröder's writing on the changing princciples of law is also important ("Die Erneuerung der Rechtswissenschaft im späten 17. Jahrhundert" pp. 213-230.), and the Study of Detlef Döring: "Die Anfänge der Ausdifferezierung der modernen Wissenschaftsdisziplinen an den deutschen protestantischen Universitäten 1670-1720" (pp. 135-162.) On knowing the new world and also on collecting/documenting and presenting this new knowledge at school: Elke Bujok: "Kunstkammerinventare und die Rezeption des Fremden um 1670" (pp. 75-97. this study is, to some extent, the history of how ethnography was born.

23 See this example: Säkularieierung in den Wissenschaften seit der Frühen Neuzeit. Band 1. Sandra Pott: Medizin, Medizinethik und schöne Literatur. Studien zu Säkularisierungsvorgängen wom frühen 17. bis zum frühen 19. Jahhundert. Berlin, New York, De Gruyter, 2002; Säkularieierung in den Wissenschaften seit der Frühen Neuzeit. Band 2. Zwischen christlicher Apologetik und methodologischem Atheismus. Wissenschaftsprozesse im Zeitraum von 1500 bis 1800. Hrsg. von. Lutz Danneberg, Sandra Pott, Jörg Schönert, Friedrich Vollhardt. Berlin, New York, De Gruyter, 2002; Säkularieierung in den Wissenschaften seit der Frühen Neuzeit. Band 3. Lutz Dabbenerg: Die Anatomie des Text-Körpers und Natur-Körpers. Das Lesen im liber naturalis und supernaturalis. Berlin, New York, De Gruyter, 2003.

24 See the telling title of Ádám Dankanits' book: A hagyományos világ alkonya Erdélyben (The decline of the traditional world in Transylvania), Budapest, Magvető, 1983 (Nemzet és emlékezet).

25 Summary: György István Tóth: Literacy and Written Culture in Early Modern Central Europe. Budapest-New York, CEU, 2000, later István György Tóth: "Illiterate and Latin-speaking gentlemen." In: The development of literate mentalities in East Central Europe. Ed. by Anna Adamska, Marco Mostert. Turnhout, Brepols, 2004. 519-528.

26 See: Zoltán Csepregi: “A magyarországi evangélikusság nyelvi és etnikai viszonyai a 16-17. század fordulóján." (The linguistic and ethnic relations within the Hungarian Lutheran community at the turn of the sixteenth and seventeenth centuries) In: Teológia és nemzetek. Az Evangélikus Hittudományi Egyetem oktatóinak tanulmánykötete. (Theology and Nations. Studies from the Lutheran University) Ed.: Lajos Szabó. Budapest, Luther Kiadó, 2016. 91-106.

27 Annamária Kónya-Péter Kónya: Szlovák reformátusok a XVI-XVIII. században. (Slovak Calvinists in the period between the sixteenth and the eighteenth centuries) Sárospatak, Hernád Kiadó, 2013.

28 Summary see István Juhász: A reformáció az erdélyi románok között. (Reformation among the Roumanians in Transylvania) Kolozsvár, Grafika nyomda, 1940.

29 For the Hungarian Kingdom see: Adorján Kulcsár: Olvasóközönségünk 1800 táján. (Readers in Hungary around 1800), Budapest, Királyi Magyar Egyetemi Nyomda 1943; Géza Fülöp: A magyar olvasóközönség a felvilágosodás idején és a reformkorban. (Hungarian Readers during Enlightenment and in the Reform Period), Budapest, Akadémiai Kiadó, 1978 (Irodalomtörténeti könyvtár, 33.); Béla Holl: Laus librorum. Válogatott tanulmányok. (Studies on Book History) Selected and edited by.: István Monok, Edina Zvara. Budapest, 2000 (METEM könyvek); Béla Holl: "Lo sviluppo del pensiero teologico alla luce del patrimonio librario del clero cattolico ungherese del primo periodo dell'Illuminismo." In: Venezia, Italia, Ungheria fra Arcadia e Illuminismo. rapporti Italo-Ungheresi dalla presa di Buda alla Rivoluzione Francese. A cura di Béla Köpeczi, Péter Sárközy. Budapest, Akadémiai Kiadó, 1982. 211-224.

30 Gyula Kornis: A magyar müvelödés eszményei 1777-1848. (The Ideals of Hungarian Education and Culture) I-II. kötet. Budapest, Egyetemi Nyomda, 1927 
31 István György Tóth: "Schichten der Gesellschaft-Schriften der Kultur. Alphabetentum und Bücherkultur im südburgerländischen Raum im XVI. und XVII. Jahrhundert.” In: Türkenkriege und Kleinlandschaft. 2. Sozialer und kultureller Wandel einer Region zur Zeit der Türkenkriege. Symposion im Rahmen der "Schlaininger Geschpräche » vom 26-30. September 1984 auf Burg Schlaining. Hrsg. von Rudolf Kropf. Eisenstadt, 1986. 195-216.; István György Tóth: "L'alphabétisation des paysans en Transdanubie occidentale au temps des Lumières." In: Début et fin des Lumières en Hongrie, en Europe Centrale et en Europe Orientale, Actes du sixième colloque de Mátrafüred 20-25 octobre 1984, publié par Ilona Kovács. Budapest-Paris, Akadémiai Kiadó, CNRS, 1987. 293-300.; István György Tóth: "La diffusione dell'alfabetizzazione nel comitato di Vas nei secoli XVII-XIX." In: Dalla liberazione di Buda all'Ungheria del Trianon. Ungheria e Italia tra età moderna e contemporanea. Atti del Convegno storico italo-ungherese (Pécs 23-24 aprile 1993) a cura di Francesco Guida. Roma, 1996. 64-71.

32 Egyed Hermann- Béla Eberhardt : A veszprémi egyházmegye papságának könyvkultúrája és könyvállománya a XIX. század elején. (Book Culture and the Book Collection of the Priests in the Veszprém Diocese at the Beginning of the $19^{\text {th }}$ Century), Veszprém, Egyházmegyei Könyvnyomda, 1942 (A veszprémi egyházmegye múltjából 8., From the Past of the Veszprém Diocese Press)

33 András Emődi: A Nagyváradi Egyházmegye alsópapságának könyvkultúrája a korai újkor végén. (The Book Culture of the Minor Clerics in the Nagyvárad Diocese), Budapest-SzegedNagyvárad, 2014 (Adattár XVI-XVIII. századi szellemi mozgalmaink történetéhez - Data for the History of the Intellectual Trends in the $16-18^{\text {th }}$ Centuries, 19/4.)

34 Róbert Oláh: “A beregi oskolamesterek olvasmányai a 18-19. század fordulóján.” (The Readings of the Schoolo Masters in Bereg at the Turn of the $18^{\text {th }}$ and $19^{\text {th }}$ Centuries) In: A tiszántúli református iskolák 18. századi könyvöröksége. (Book Heritage of the Schools of he Reformed Church in Transtisza or Tiszántúl in the $18^{\text {th }}$ Century) Tanulmányok. (Studies) Edited by.: István Monok. Budapest-Eger, Kossuth Kiadó, EKF, 2012 (Kulturális örökség - Cultural Heritage) $151-238$.

35 Antal Laszkalner: “A könyvolvasásrúl,” (On reading Books) Egyházi folyóirás, kiad. Mátyás Kováts, 2-dik füzet, Pest, Beimel Jósef, 1832, 49-108.

36 Antal Laszkalner: A könyvolvasásról, (On reading Books) Második, néhány tárgyfejtegetö érdekes jegyzésekkel 's egy uj szerkezetü toldalékkal bövitett kiadás, (Second revised edition with some intersting comments and new supplement), Veszprém, Ramasetter Károly, 1848.

37 Menyhért Palágyi: Az ismerettan alapvetése. (Basics of Epistemology) Budapest, Atheneum, 1904. 28-30. (Learning to read, syllabification, reading aloud, reading to oneself, and the correlation between knowing and abstract knowledge); See.: Tamás Demeter: "A kommunikáció iránti érdeklődés megélénkülése a századelőn." (A Growing Interest for Communication at the Beginning of the Century) In: "Szerep és közeg. Medialitás a magyar kultúratudományok 20. századi történetében." (A Role and the Medium, Mediality in the Hungarian cultural history of the $20^{\text {th }}$ Century) Ed. by. Szabolcs Oláh, Attila, Simon, Péter Szirák, Budapest, Ráció, 2006 (Ráció - Tudomány - Ratio and Science, 9) 207-222. (especially: 208-212.); Demeter Tamás: A szociologizálódó hagyomány, A magyar filozófia fóárama a XX. században. (Sociological Tradition, The Main Trend in Hungarian Philosophy in the $20^{\text {th }}$ Century) Budapest, Századvég, 2011, On Palágyi pp. 44-56., especially pp. 48-49.: Palágyi’s references to Humbold, Herder or Hegel in connection with reading, writing and the mechanisms of thinking; Béla Lóránt Kovács: "Képzelet és ihlet. Palágyi Menyhért a filozófia és az irodalom medialitásáról." (Imagination and Inspiration. Menyhért Palágyi on the mediality of Philosphy and Literature) In: Az olvasás rejtekútjai. Müfajiság, kulturális emlékezet és medialitás a 20. századi magyar irodalomtudományban. (Secret pathways of Readng. Genres, cultural remembrance and mediality in the $20^{\text {th }}$ century Hungarian literature) edited by Tibor Bónus, Zoltán Kulcsár-Szabó, 
Attila Simon, Budapest, Ráció, 2007 (Ráció - Tudomány -- Ratio and Science, 12), 51-71. (itt: 55-57.); Katalin Neumer: "Magyar filozófia, osztrák filozófia, I. rész" (Hungarian philosophy, Austrian philosophy), BUKSZ (Budapesti könyvszemle), 25(2013), Nr. 4., 314-328. (especially: 323-324.)

38 Palágyi: Az ismerettan ... (Epistemology), 1904, 30.

39 “Miután az Akadémia 1830-ban ténylegesen megkezdte múködését, egyik első lépésként bizottságot alapított, amely 1831. május 16-i ülésén a magyar színpadi repertoár és a magyar nyelv gazdagítása érdekében 71 lefordítandó színjátékot sorolt fel. Ebből huszonkettő Shakespeare darab volt." (When the Academy started its operation in 1830, one of its first measures was to set up a committee, which listed 71 plays at their session on May 16th, 1831 to improve the Hungarian theatrical repertoire and Hungarian language. 22 out of these 71 were plays written by Shakespeare.) See Antal Babus: "Vörösmarty, Shakespeare magyar fordítója." In: 180 éves a Szózat. A Magyar Tudományos Akadémia Könyvtár és Infromációs Központ Vörösmarty-kiállitása. 2016. november 3-tól 2017. március 15-ig. Ed. by.: Antal Babus. Budapest, MTA KIK, 2016. 25. It is worth noting that Vörösmarty translated Shakespeare from German. See.: A Magyar Tudományos Társaság évkönyvei. Elsö kötet. (Yearbooks of the Hungarian Scholarly Society, Volume One), Pest, Trattner-Károlyi, 1831. 73.

40 To avoid any misunderstandings let me stress here that there is nothing wrong with developping theories. What I have problems with is people who justify their laziness by acquainting themselves only with theories and not history and pretend to be "modern" by citing the titles of contemporary theoretical books (memory history, lieu de mémoires, etc.). 